\title{
PENDIDIKAN KESEHATAN UNTUK MENINGKATKAN PENGETAHUAN TERHADAP PENYAKIT MENULAR SEKSUAL PADA ANAK RENTAN EKSPLOITASI DI DAERAH KUTA LOMBOK TENGAH
}

\author{
Rias Pratiwi Safitri ${ }^{11}$, Fitri Romadonika1), Baiq Nurul Hidayati1), Harlina Putri Rusiana1), \\ Ni Putu Ariyani"1), Baiq Mara Wardatun Najwa1) \\ 1)STIKES Yarsi Mataram, Mataram, NTB, Indonesia \\ Corresponding Author : Fitri Romadonika \\ E-mail:romadonika.fitri@gmail.com
}

Diterima 23 November 2021, Direvisi 27 November 2021, Disetujui 28 November 2021

\begin{abstract}
ABSTRAK
Tempat wisata memiliki potensi eksploitasi anak sangat besar mengingat mudahnya wisatawan datang berkunjung. Banyak dari mereka tidak hanya datang berlibur dan melakukan bisnis, ada yang memiliki motif lain salah satunya mengeksploitasi anak secara seksual. Terdapat data anak rentan eksploitasi seksual komersial wilayah Lombok tengah yang mencakup tiga desa (Wajageseng, Kuta, Rembitan) pada tahun 2019 berjumlah 550 orang. Tujuan pengabdian ini untuk meningkatkan pengetahuan tentang kesehatan reproduksi pada anak yang merupakan hasil kaderisasi dari GAGAS Foundation yang fokus menangani masalah ekspolitasi anak di daerah tersebut. Dengan luaran kader dapat melakukan pendidikan kesehatan reproduksi pada setiap anak rentan dan meningkatkan kesadaran mereka terhadap bahaya penyakit menular seksual di daerah wisata. Metode yang digunakan pengukuran tingkat pengetahuan tentang penyakit menular seksual, setelah itu pelatihan sebanyak 3 kali pertemuan, serta pengukuran kembali. Jumlah responden 10 orang. Didapatkan hasil peningkatan tentang penyakit menular seksual pada anak rentan eksploitasi. Rekomendasi diharapkan dapat menyebarluaskan dan memberikan penjelasan pada anak yang berada diwilayah asalnya dan mampu mengaplikasikan materi yang telah disampaikan dalam kehidupan sehari hari,kepada Instansi Pemerintahan Desa Kuta Lombok Tengah diharapkan dapat memberikan akses pendidikan sehingga pengetahuan anak meningkat dan dapat menurunkan angka kejadian penyakit menular seksual, lebih meningkatkan kesadaran dalam partisipasinya mencegah terjadinya penyakit menular seksual.
\end{abstract}

Kata kunci: anak rentan eksploitasi; pendidikan kesehatan; pengetahuan tentang penyakit menular seksual

\begin{abstract}
Tourism places have large potential for child exploitation considering the ease way of tourists comes to visit. Many of them don't just come on vacation and do business, some have other motives, one of which is sexually exploiting children. There was data on children vulnerable to commercial sexual exploitation at Central Lombok area which includes three villages (Wajageseng, Kuta, Rembitan) in 2019 totaling 550 people. The aimed of this research was to increase the knowledge about reproductive health on children which the result of regeneration from the GAGAS Foundation which focuses on dealing with the problem of child exploitation in that area. With the output of these cadres who carry out the reproductive health education for every vulnerable child and to increase their awareness of the dangers of sexually transmitted diseases on these tourism areas. The method was carried out with measuring the level of knowledge about sexually transmitted diseases, after that conducting training for 3 meetings, and measuring again. the number of respondents were 10 people. Based on the results of the paired sample T test, the result is $0.000(p<0.05)$, which means that there is an increase of knowledge about sexually transmitted diseases on vulnerable exploitation children. Recommendations are expected to be able to disseminate and provide explanations to children who are in their original area and able to apply the material that has been conveyed in daily life, and to Government Agency of Central Lombok, it is hoped that they can provide access to education for children so that children's knowledge increases and can reduce incidence rates. sexually transmitted diseases, increasing awareness on their participation in preventing the occurrence of sexually transmitted diseases.
\end{abstract}

Keywords: vulnerable exploitation children; health education; knowledge of sexually transmitted diseases 


\section{PENDAHULUAN}

Eksploitasi seksual komersial anak (ESKA) merupakan bentuk paksaan dan kekerasanterhadap anak dan sejumlah tenaga kerja paksa dan bentukperbudakan modern. Sebuah pernyataan dari Kongres Dunia untuk melawan Eksploitasi Seksual Komersial Anak, yang diselenggarakan di Stockholm padatahun 1996, mendefinisikan ESKA sebagai: pelecehan seksual oleh orang dewasa dan remunerasi tunai atau barang kepada anak atau orang ketiga atau orang lain. Anak diperlakukan sebagai objek seksual dan sebagai objek komersial.ESKA termasuk pelacuran anak, pornografi anak, pariwisata seks anak dan bentuk lain dari transaksional seksual di mana seorang anak terlibat dalam kegiatan seksual untuk dapat memiliki kebutuhan utama yang terpenuhi, seperti makanan, tempat tinggal atau akses ke pendidikan. Ini termasuk bentuk transaksional seksual di mana kekerasan seksual terhadap anak tidak dihentikan atau dilaporkan oleh anggota keluarga, karena manfaat yang diperoleh oleh keluarga dari pelaku. ESKA juga berpotensi mencakup perjodohan yang melibatkan anak di bawah usia 18 tahun, di mana anak belum bebas menyetujui pernikahan dan di mana anak mengalami pelecehan seksual.

LPSK mencatat ada peningkatan kasus kekerasan seksual pada anak yang terjadi sejak 2016 sejumlah 25 kasus, lalu meningkat pada 2017 menjadi 81 kasus, dan puncaknya pada 2018 menjadi 206 kasus. Sampai dengan bulan Juni 2019 telah mencapai 78 permohonan terhadap kasus kekerasan seksual terhadap anak (detiknews). Plt Deputi Bidang Koordinasi Perlindungan Perempuan dan Anak Kemenko menyampaikan Indonesia Darurat Pornografi, hal ini sesuai dengan data bahwa 50.000 aktivitas pornografi setengahnya adalah pornografi anak. Dari Januari s.d Agustus 2018, kekerasan terhadap anak dan kekerasan seksual anak, kasus pencabulan terjadi 141 kali, pemerkosaan 120 kali, sodomi 36 kali dan inses 19 kali. Pada tahun2018, komisi perlindungan anak (KPAI) juga mencatat ada 80 kasus prostitusi anak, 75 kasus eksploitasi pekerja anak, dan 57 kasus eksploitasi seksual komersial pada anak, dan 52 kasus trafficking (Ecpatindonesia). Pada tahun 2019, KPAl catat tindak pidana perdagangan orang (TPPO)/ anak dan eksploitasi hingga bulan agustus mencapai 154 kasus (Nasional news).

Yayasan Galang Anak Semesta (GAGAS) dalam program down to zero yang berada di
Lombok mencatat bahwa terdapat data anak rentan eksploitasi seksual komersial wilayah lombok tengah yang mencakup tiga desa pada tahun 2019 berjumlah 550 orang. Dengan rincian pada desa Wajageseng sebanyak 219 anak, desa Kuta sebanyak 296 anak, dan wilayah Rembitan terdapat data mulai dari 2018 sampai 2019 berjumlah 260 orang (Gagas, 2019). Dilihat dari data di atas menunjukkan bahwa anak sangat beresiko rentan terkena penyakit menular seksual. penyakit menular seksual (PMS) merupakan penyakit yang menular melalui hubungan seksual (hubungan kelamin). Penyakit menular ini akan lebih beresiko bila melakukan hubungan seksual dengan berganti ganti pasangan baik melalui vagina, oral, maupun anal (Kusmiran, 2011).

Menurut Dr. Hanny Nilasari Sp.KK(K), pasien infeksi menular seksual kini makin marak yang berusia remaja. Bahkan ada yang masih usia Sekolah Menengah Pertama. Data di RSCM menunjukkan bahwa sekitar $15 \%$ dari kasus IMS baru yang dilaporkan, terdiri dari anak berusia 12-22 tahun. Sementara RSUD Soetomo, Surabaya, mencatat ada sekitar 30 pasien IMS berusia muda setiap bulannya (Wasitaatmadja \& Norawati, 2018). Maraknya pasien terinfeksi oleh penyakit menular seksual menimbulkan kekhawatiran. Kurangnya pemahaman yang tepat atau informasi yang salah mengenai masalah seksualitas menyebabkan resiko tinggi tertular PMS. Perilaku seksual yang tidak aman, penyalahgunaan jarum suntik saat menggunakan narkotika, dapat meningkatkan resiko penyebaran penyakit menular seksual (Wasitaatmadja \& Norawati, 2018).

Ketika dilakukan observasi terhadap kegiatan pekerjaan yang melibatkan anak yang terjadi di daerah wisata Kuta Lombok Tengah. Relawan GAGAS beserta PSIKIATER mendapatkan fakta bahwa banyak anak yang tereksploitasi seksual, dimana anak diantar oleh orang tuanya ke klab malam dan akan dijemput pada jam 03 pagi. Kegiatan tersebut dilakukan di tempat yang berpindah pindah setiap malam. Saat dilakukan studi pendahuluan pada anak eksploitasi maupun yang rentan eksploitasi yang berada di Kuta Lombok Tengah pada tanggal 30 november 2019 dengan 7 responden. Dalam survey awal, hasil observasi pada wilayah Kute terdapat banyak anak yang tereksploitasi karena kurangnya penghasilan sehingga mengakibatkan anak ikut andil dalam memenuhi kebutuhan. Maraknya budaya pernikahan dini dan pendidikan yang rendah 
sehingga menyebabkan pengetahuannya kurang terkait penyakit menular seksual yang memicu terjadinya eksploitasi pada anak.

Saat dilakukan wawancara pada 3 orang responden laki laki dan 4 responden perempuan terkait penyakit menular seksual menunjukkan hasil bahwa 3 diantaranya mengetahui tentang penyakit menular seksual, sedangkan 4 orang lainnya tidak mengetahui dan memahami terkait dengan penyakit menular seksual dikarenakan ketika ditanya tentang penyakit menular seksual beserta jenisnya, mereka terlihat bingung dan menunjukkan temannya yang lain untuk menjawab pertanyaan (Observasi Dan Wawancara, 2019). Hasil penelitian dari (Wasitaatmadja \& Norawati, 2018), yaitu menyimpulkan bahwa pengetahuan tentang penyakit menular seksual yang rendah dapat meningkatkan perilaku seksual tidak aman pada remaja.

Untuk meningkatkan pengetahuan tentang PMS, di butuhkan pendidikan kesehatan seksual untuk mengurangi resiko tinggi menular seksual. Pendidikan seksual atau edukasi seks adalah kegiatan untuk mengajarkan mengenai kesehatan reproduksi. Tujuan kegiatan ini adalah untuk menyadarkan pentingnya kesehatan reproduksi sehingga tindakan pelecehan seksual maupun penyakit menular dapat dicegah. Menurut (Suryagustina et al., 2017) mendapatkan kesimpulan bahwa pendidikan kesehatan berpengaruh terhadap tingkat pengetahuan pasien tentang pencegahan infeksi menular seksual. Hasil penelitian yang dilakukan oleh (Afifah, 2019) menunjukkan bahwa ada hubungan pengetahuan tentang pendidikan seks dengan perilaku seksual remaja.Berdasarkan uraian dan data diatas maka urgensi untuk memberikan Pendidikan Kesehatan Untuk Meningkatkan Pengetahuan Terhadap Penyakit Menular Seksual Pada Anak Rentan Ekspolitasi Di Daerah Kuta Lombok Tengah.

\section{METODE}

Dalam pengabdian ini menggunakan metode kuantitatif pra-eksperimen dengan rancangan one group pre-test-post-test, dimana kelompok subjek diobservasi sebelum dan sesudah dilakukan intervensi untuk mengetahui efektivitas pendidikan kesehatan seksual level III untuk meningkatkan pengetahuan tentang penyakit menular seksual pada anak rentan eksploitasi.

Lokasi penelitian dilakukan di Sanggar Anak Kuta Lombok Tengah pada tanggal 29 dan 30 Agustus 2020. Populasi dalam penelitian ini adalah kader anak yang tergabung dan masih aktif dalam kegiatan sanggar anak yang berada di wilayah kuta Lombok tengah sebanyak 10 orang.Sanggar anak yaitu tempat anak-anak untuk mempelajari suatu hal tertentu selain dari kegiatan sekolah, dan lain-lain. Sanggar anak terdapat kader yang bertugas sebagai penyebarluasan dan memberikan penjelasan pada anak yang berada di wilayah asalnya terkait dengan pengetahuan yang diberikan ketika mengikuti kegiatan sanggar.Sampel dalam penelitian ini adalah kader anak rentan eksploitas yang tergabung dan masih aktif dalam kegiatan sanggar anak yang berada di wilayah Kuta Lombok Tengah sebanyak 10 orang. Dalam penelitian ini, pengambilan sampel dilakukan dengan cara kuota sampling. Instrumen penelitian adalah alat atau fasilitas yang digunakan oleh peneliti dalam mengumpulkan data agar pekerjaannya lebih mudah dan hasilnya lebih baik (cermat, lengkap dan sistematis) sehingga lebih mudah diolah (Saryono, 2013), Blue print dalam kuisioner pengetahuan tentang penyakit menular seksual adalah sebagai berikut:

Tabel 1. Blue Print Kuisioner Pengetahuan Tentang Penyakit Menular Seksual.

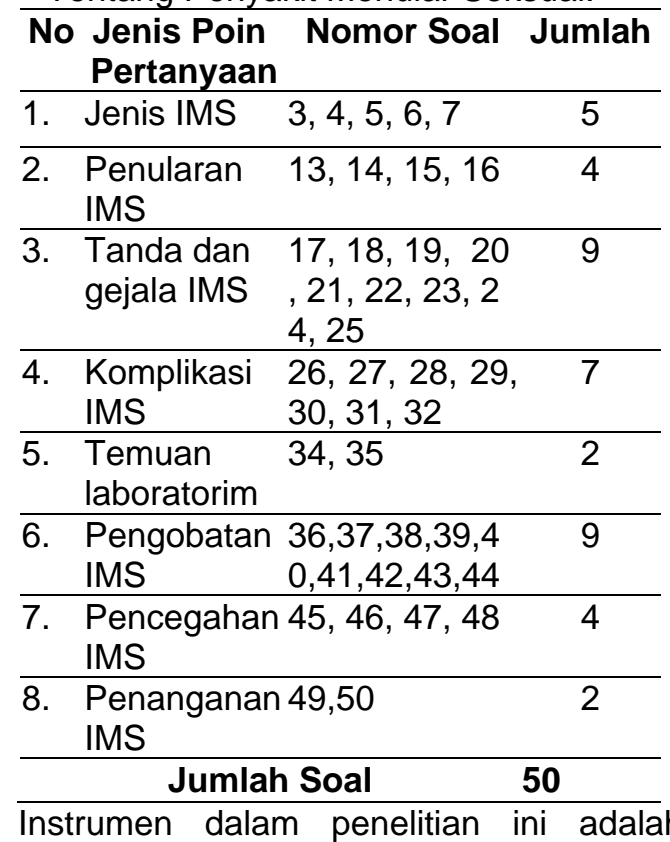
kuisioner Pengetahuan Tentang Penyakit Menular Seksual yang diadaptasi dari peneliti (Astuti et al., 2017) yang telah diuji validitas dan reliabilitas dengan angka 0,709 yang berarti bisa dipercaya dan valid digunakan sebagai alat untuk mengumpulkan data. Pertanyaan kuisioner ini bertujuan untuk mengetahui tingkat pengetahuan tentang penyakit menular seksual pada anak rentan eksploitasi dengan jumlah pertanyaan kuisioner untuk pengetahuan tentang penyakit menular seksual terdiri dari 20 pertanyaan. 
HASIL DAN PEMBAHASAN

Hasil

a. Tingkat pengetahuan sebelum
pendidikan kesehatan seksual pada
anak rentan eksploitasi

Tabel 1. Distribusi Tingkat Pengetahuan

Responden Sebelum Dilakukan Pendidikan Seksual Pada Anak Rentan Eksploitasi Di

Wilayah

\begin{tabular}{llll}
\hline $\begin{array}{l}\text { No Kategori } \\
\text { Pengetahuan }\end{array}$ & $\begin{array}{l}\text { Pre- } \\
\text { test }\end{array}$ & $\%$ \\
\hline 1 & Baik & 0 & 0 \\
\hline 2 & Sedang & 7 & 70 \\
\hline 3 & Rendah & 3 & 30 \\
\hline & Total & & $\mathbf{1 0 0}$ \\
\hline
\end{tabular}

Berdasarkan tabel 1 didapatkan bahwa mayoritas katagori pengetahuan responden sebelum dilakukan pendidikan seksual terdapat pada kategori cukup sebanyak 7 orang $(70 \%)$ dan pengetahuan responden dengan katagori rendah berjumlah 3 orang (30\%) dari 10 responden.

\section{b. Tingkat pengetahuan sesudah pendidikan kesehatan seksual pada anak rentan eksploitasi}

Tabel 2. Distribusi Tingkat Pengetahuan

Responden Sesudah Dilakukan Pendidikan

Seksual Pada Anak Rentan Eksploitasi Di Wilayah Kuta Lombok Tengah

\begin{tabular}{llll}
\hline No. & $\begin{array}{l}\text { Kategori } \\
\text { Pengetahuan }\end{array}$ & $\begin{array}{l}\text { Post- } \\
\text { test }\end{array}$ & $\%$ \\
\hline 1 & Baik & 10 & 100 \\
\hline 2 & Sedang & 0 & 0 \\
\hline 3 & Rendah & 0 & 0 \\
\hline & Total & 100 \\
\hline
\end{tabular}

Berdasarkan tabel 2 katagori pengetahuan responden setelah dilakukan pendidikan seksual terdapat pada kategori baik sebanyak 10 orang (100\%) dimana data dari post test menyatakan bahwa katagori pengetahuan semua responden berada dalam katagori baik.

c. Analisis Efektivitas Pendidikan Seksual Untuk Meningkatkan Pengetahuan Tentang Penyakit Menular Seksual Pada Anak Rentan Eksploitasi

Tabel 3. Distribusi Pengetahuan Responden Sebelum Dan Sesudah Dilakukan Pendidikan Seksual Pada Anak Rentan Eksploitasi Di Wilayah Kuta Lombok Tengah

\begin{tabular}{|c|c|c|c|c|}
\hline No & Pre-post & Mean & $\begin{array}{c}\text { Std. } \\
\text { devation }\end{array}$ & $\begin{array}{l}\text { iign (2- } \\
\text { tailed) }\end{array}$ \\
\hline 1 & Pre-test & 57.50 & 7.472 & \multirow{3}{*}{0.000} \\
\hline 2 & Post-test & 90.60 & 5.481 & \\
\hline 3 & $\begin{array}{c}\text { Pre-post } \\
\text { test }\end{array}$ & -33.100 & 9.769 & \\
\hline
\end{tabular}

Dari hasil uji paired sample $T$ test didapatkan $p$ value $0.000<\alpha=0.05$ dengan menggunakan SPSS dimana terjadi perbedaan yang signifikan terkait dengan peningkatan pengetahuan tentang penyakit menular seksual pada anak rentan eksploitasi di Wilayah Kuta Lombok Tengah sebelum dan sesudah diberikan pendidikan kesehatan sebagai intervensi sehingga dapat disimpulkan adanya efektivitas pendidikan kesehatan untuk meningkatkan pengetahuan tentang penyakit menular seksual pada anak rentan eksploitasi.

d. Gambaran Kegiatan Pendidikan Kesehatan di Sanggar Anak GAGAS

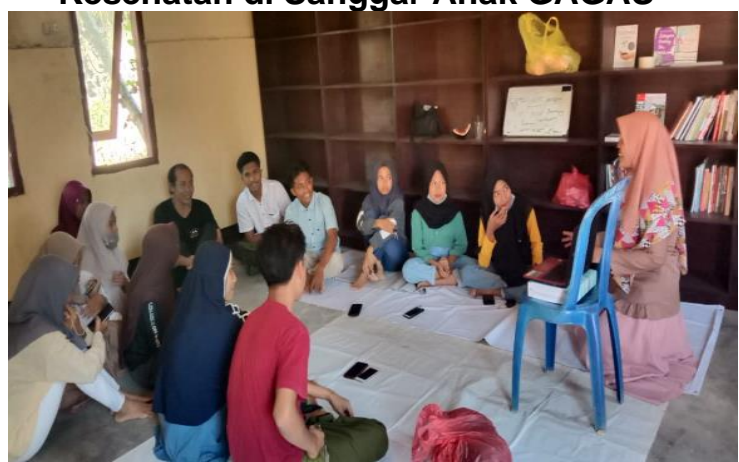

Gambar 1. Kegiatan Pendidikan Kesehatan

\section{Pembahasan}

Berdasarkan hasil uji paired sample $T$ test dari data pre-post test didapatkan hasil $0.000(p<0.05)$, yang artinya Ho ditolak dan $\mathrm{Ha}$ diterima. sehingga dapat disimpulkan bahwa terdapat adanya efektivitas pendidikan seksual untuk meningkatkan pengetahuan tentang penyakit menular seksual pada anak rentan eksploitasi sehingga pretest dan posttest mengalami perubahan yang signifikan (berarti).Hal ini sesuai dengan hasil penelitian dari (Akbar \& Muzdalifah, 2014) dengan judul Program Pendidikan Seks Untuk Meningkatkan Proteksi Diri Dari Eksploitasi Seskual Pada Anak Usia Dini mendapatkan didapatkan Hasil uji statistik p-value 0,000 < dari nilai 0,05 sehingga terdapat pengaruh pendidikan kesehatan terhadap tingkat pengetahuan tentang pencegahan infeksi menular seksual dimana hasil analisis antara kelompok eksperimen yang mendapatkan perlakuan pada pengukuran sebelum (pre-test) dan sesudah perlakuan (post-test) menemukan yaitu $t=5,548, p=0,000<0,05$ (signifikan). Artinya, ada perbedaan yang signifikan pada kelompok eksperimen antara sebelum dan sesudah perlakuan diberikan.

Menurut (Soekidjo, 2012) faktor-faktor yang mempengaruhi pengetahuan diantaranya pendidikan, informasi atau media masa, pekerjaan, lingkungan, pengalaman, usia, sosial, budaya, dan ekonomi.Berdasarkan penelitian yang dilakukan di Wilayah Kuta 
Lombok Tengah, didapatkan bahwa karakteristik responden berdasarkan umur jumlah responden terbanyak adalah responden yang berusia 14 tahun dengan jumlah 6 orang $(60 \%)$ dari 10 responden. Sedangkan responden yang berumur 15 sebanyak 4 orang $(40 \%)$.

Hal tersebut sesuai dengan penelitian (Ayu \& Susanto, 2019) dengan judul Hubungan Pendidikan Dan Status Kawin Dengan Infeksi Menular Seksual Pada Wanita Usia Subur Di Layanan Klinik IMS menjelaskan kelompok remaja umur (13-20 tahun) terdapat 15 orang (14\%), pada kelompok dewasa awal (21-35 tahun) terdapat 66 orang $(61,7 \%)$, pada kelompok dewasa pertengahan (36-45 tahun) terdapat 26 orang (24,3\%). Wanita usia muda paling berisiko tertular IMS karena para wanita remaja dan dewasa muda lebih mudah terpengaruh secara tidak proporsional. Mereka lebih sering terlibat dalam perilaku seksual berisiko, merasa tidak nyaman membicarakan seksual yang aman dengan pasangan atau meminta pasangan menggunakan kondom serta kurang percaya diri menolak hubungan seksual yang tidak aman.

Wilayah Kuta Lombok Tengah, didapatkan bahwa karakteristik responden berdasarkan jenis kelamin responden bermayoritas perempuan dengan jumlah 7 orang $(70 \%)$ dari 10 responden. Sedangkan responden laki-laki sebanyak 3 orang (30\%).Penelitian ini didukung oleh hasil penelitian (Afifah, 2019) dengan judul Hubungan Pengetahuan Tentang Penyakit Menular Seksual Terhadap Jenis Kelamin Pada Siswa-Siswi Man 2 Banyumas melakukan analisis statistik untuk mencari hubungan antara tingkat pengetahuan dan jenis kelamin sebelum dilakukan serangkaian kegiatan didapatkan nilai $p>0,05$, hal itu menunjukkan bahwa tidak terdapat hubungan antara tingkat pengetahuan tentang penyakit melular seksual dengan jenis kelamin pada siswa-siswi MAN 2 Banyumas.

Selain itu, karakteristik responden berdasarkan pendidikan sebanyak 10 orang $(100 \%)$ pada tingkat SMP, yang artinya semua responden dalam penelitian ini sedang menempuh pendidikan SMP.Penelitian ini sejalan dengan penelitian ayu \& susanto (2019) dengan judul Hubungan Pendidikan Dan Status Kawin Dengan Infeksi Menular Seksual Pada Wanita Usia Subur Di Layanan Klinik IMS mendapatkan hasil Tingkat pendidikan tidak memiliki hubungan dengan IMS. Hal ini disebabkan oleh jumlah yang tidak berisiko (tingkat pendidikan tinggi) sebanyak 74 orang (yang didiagnosa IMS sebanyak 31 orang $\leq$ yang tidak didiagnosa IMS sebanyak
43 orang). Sedangkan yang berisiko (pendidikan rendah) sebanyak 33 orang (yang didiagnosa IMS sebanyak 11 orang $\leq$ yang tidak didiagnosa IMS sebanyak 22 orang) dan peneliti juga menganalisis bahwapendidikan bukan satu - satunya cara untuk mencegah terjadinya IMS, tetapi dapat dilakukan dengan meningkatkan pengetahuan tentang kesehatan reproduksi.

Hasil evaluasi yang didapatkan setelah dilakukan pendidikan kesehatan seksual mampu meningkatkan pengetahuan responden terkait dengan penyakit menular seksual (PMS) dimana responden terlihat menyimak video, responden juga terlihat memperhatikan apa yang dijelaskan oleh peneliti, aktif bertanya ketika sesi Tanya jawab, dan terlihat ikut berpartisipasi dalam kegiatan diskusi. Sehingga pada saat dilihat hasil post test responden banyak terdapat pernyataan yang mendapatkan skor tertinggi dimana responden mampu mengetahui pengertian dan penyebab penyakit menular seksual (PMS), jenis-jenis, tanda dan gejala, bahaya serta pencegahan PMS.

\section{SIMPULAN DAN SARAN}

Kesimpulan hasil yang didapatkan yaitu terdapat efektivitas pendidikan kesehatan untuk meningkatkan pengetahuan tentang penyakit menular seksual pada anak rentan ekspolitasi seksual yang di buktikan oleh hasil data pretest dengan katagori cukup dan kurang sehingga hasil data posttest meningkat menjadi baik setelah dilakukan pendidikan kesehatan seksual dengan hasil 0.000 ( $p<$ 0.05 ) sehingga $\mathrm{Ha}$ diterima.Dengan pendidikan kesehatan seksual dapat mencegah terjadinya tindakan pelecehan seksual sehingga dapat mengetahui dampak, akibat, serta mengurangi penderita penyakit menular seksual. Pendidikan kesehatan seksual juga dapat mencegah terjadinya tindakan pelecehan seksual untuk mencegah dampak dampak negative yang tidak diharapkan, seperti kehamilan yang tidak direncanakan, terpapar penyakit menular seksual, depresi, perasaan berdosa, sehingga pencegahan tersebut dapat mengurangi penderita penyakit menular seksual.

\section{DAFTAR RUJUKAN}

Afifah, A. (2019). Hubungan Pengetahuan Tentang Penyakit Menular Seksual Tehadap Jenis Kelamin Pda SiswaSiswi MAN 2 Banyumas. Prosiding, $8(1)$.

Akbar, Z., \& Muzdalifah, F. (2014). Program pendidikan seks untuk meningkatkan proteksi diri dari eksploitasi seksual 
pada anak usia dini. Parameter: Jurnal Pendidikan Universitas Negeri Jakarta, 25(2), 115-122.

Astuti, D. Y., Santoso, S., \& Estiwidani, D. (2017). Hubungan Tingkat Pengetahuan dengan Kejadian Infeksi Menular Seksual pada Wanita Usia Subur di Puskesmas Sleman. Poltekkes Kemenkes Yogyakarta.

Ayu, S. M., \& Susanto, I. (2019). Hubungan Pendidikan dan Status Kawin dengan Infeksi Menular Seksual pada Wanita Usia Subur di Layanan Klinik IMS. Kes Mas: Jurnal Fakultas Kesehatan Masyarakat, 13(2), 56-61.

Kusmiran, E. (2011). Kesehatan reproduksi remaja dan wanita. Jakarta: Salemba Medika, 21.

Saryono, A. (2013). Metodologi penelitian kualitatif dan kuantitatif dalam bidang kesehatan. Yogyakarta: Nuha Medika.

Soekidjo, N. (2012). Promosi kesehatan dan perilaku kesehatan. Jakarta: Rineka Cipta, 131-132.

Suryagustina, S., Sianipar, S. S., \& Manipada, L. K. (2017). Pengaruh Pendidikan Kesehatan Terhadap Tingkat Pengetahuan Pasien Tentang Pencegahan Infeksi Seksual Di Wilayah Kerja Puskesmas Raya Palangka Raya. An-Nadaa: Jurnal Kesehatan Masyarakat, 4(1), 31-34.

Wasitaatmadja, S. M., \& Norawati, L. (2018). Pedoman Diagnosis dan Tatalaksana Melasma di Indonesia. Universitas Indonesia Publishing. 